\title{
THE IMPACT OF RACE ON POLICING AND ARRESTS*
}

\author{
JOHN J. DONOHUE III \\ and \\ STEVEN D. LEVITT \\ Stanford Law School \\ University of Chicago \\ and AmericanBar \\ Foundation
}

\begin{abstract}
Race has long been recognized as playing a critical role in policing. In spite of this awareness, there has been little previous research that attempts to quantitatively analyze the impact of officer race on tangible outcomes. In this paper, we examine the relationship between the racial composition of a city's police force and the racial patterns of arrests. Increases in the number of minority police are associated with significant increases in arrests of whites but have little impact on arrests of nonwhites. Similarly, more white police increase the number of arrests of nonwhites but do not systematically affect the number of white arrests. These patterns are particularly striking for minor offenses. Understanding the reasons for this empirical regularity and the consequent impact on crime is an important subject for future research.
\end{abstract}

$\mathbf{R}$

ACE is a polarizing feature in American society. Nowhere is this more evident than in the criminal justice system. African Americans, who comprise 12 percent of the U.S. population, account for 47 percent of felony convictions and 54 percent of prison admissions. Studies suggest that one-third of AfricanAmerican males aged 20-29 are under the supervision of the criminal justice system on any given day. ${ }^{1}$ Minority communities are often suspicious of and hostile toward the criminal justice system in general and police in particular. $^{2}$

* We would like to thank Dhammika Dharmapala, Lawrence Katz, Rob Sampson, two anonymous referees, and seminar participants at the Columbia Law School, Haas School of Business, National Bureau of Economic Research summer institute, Stanford Law School, and University of Southern California Law School for comments and suggestions. We would also like to thank Ron Edwards, chief of the Research and Technical Information Branch of the Equal Employment Opportunity Commission, for his cooperation in providing some of the data used. Michael Friedlander, Connie Taylor, and Justin Wood provided truly exemplary research assistance.

${ }^{1}$ Marc Mauer \& Tracey Huling, Young Black Americans and the Criminal Justice System: Five Years Later (1995).

${ }^{2}$ U.S. Kerner Comm'n, Report of the National Advisory Comm'n on Civil Disorders (1968); R. Mast, Police-Ghetto Relations: Some Findings and a Proposal for Structural Change, 11 RACE 447 (1970); NAACP, Beyond the Rodney King Story: An Investigation of Police Conduct in Minority Communities (1995).

[Journal of Law and Economics, vol. XLIV (October 2001)]

(C) 2001 by The University of Chicago. All rights reserved. 0022-2186/2001/4402-0002\$01.50 
Conflicts between police and citizens have been the flashpoint for virtually every recent urban riot.

As early as the Kerner Commission report, ${ }^{3}$ the potential social benefits of minority police officers have been recognized. Minority officers may have an advantage when it comes to dealing with problems in predominantly minority neighborhoods, both because of a greater understanding of cultural norms and because of increased community acceptance. It is frequently argued that without the cooperation of community members in reporting crimes and identifying criminals, there may be little that police can do either to prevent crime or to punish those who commit crimes. ${ }^{4}$ Same-race police may lead to a greater willingness of victims of crime to report offenses to the police, an increased ability to solve cases owing to community cooperation, and a reduction in the number of unjustified arrests or police harassment. The implication of such arguments is that matching police patrols to neighborhoods by race or ethnicity may provide social benefits.

On the other hand, if police are more reluctant to arrest suspects of their own race even when the arrest is justified (as might be predicted from research in social psychology), ${ }^{5}$ same-race policing may be less effective in reducing crime than cross-race policing. Furthermore, the possibility of police corruption may increase with same-race policing. ${ }^{6}$ Enforcement of illicit contracts between enterprises engaged in criminal activities (for example, gangs, organized crime, and chop shops) and the police may be easier within a racial or ethnic group. There is ample anecdotal evidence of police-related

${ }^{3}$ U.S. Kerner Comm'n, United States Kerner Commission Report (1968).

${ }^{4}$ James Q. Wilson, Thinking about Crime (1983); Wesley Skogan, Fear of Crime and Neighborhood Change, in Crime and Justice: A Review of Research (Michael H. Tonry \& Norval Morris eds. 1986); Jerome H. Skolnick \& David H. Bayley, The New Blue Line: Police Innovation in Six American Cities (1986); Mark Harrison Moore, Problem-Solving and Community Policing, in Modern Policing (Michael Tonry \& Norval Morris eds. 1992); George Akerlof \& Janet L. Yellen, Gang Behavior, Law Enforcement, and Community Values, in Values and Public Policy (Henry J. Aaron, Thomas E. Mann, \& Timothy Taylor eds. 1994).

${ }^{5}$ Faye Crosby, Stephen Bromley, \& Leonard Saxe, Recent Unobtrusive Studies of Black and White Discrimination and Prejudice, 87 Psychol. Bull. 546 (1980); Linda Hamilton Krieger, The Content of Our Categories: A Cognitive Bias Approach to Discrimination and Equal Employment Opportunities, 47 Stan. L. Rev. 1161 (1995).

${ }^{6}$ If favoritism or corruption operated powerfully for within-race policing, then these factors might argue for increased minority hiring with greater cross-race policing. That is, under these assumptions, the optimal allocation of minority officers would be to predominantly white neighborhoods, and vice versa. Roger Bowles \& Nuno Garoupa, Casual Police Corruption and the Economics of Crime, 17 Int'l Rev. L. \& Econ. 75 (1997), provides a recent theoretical examination of police corruption. In addition, there is a burgeoning literature on corruption more generally. Important contributions to this literature include Andrei Shleifer \& Robert W. Vishny, Corruption, 108 Q. J. Econ. 599 (1993); Paolo Mauro, Corruption and Growth, 110 Q. J. Econ. 681 (1995); and Mancur Olson, Jr., Why Poor Economic Policies Must Promote Corruption: Lessons from the East for All Countries, 111 Rivista di Politica Economica 9 (1996). 
corruption. ${ }^{7}$ In fact, widespread corruption was one of the critical factors underlying the initial movement away from politically based police appointments and toward the professionalization of policing. ${ }^{8}$

In spite of the importance of the issue of race in policing, we are aware of very little relevant academic research that tries to directly assess the influence of race on arrests and crime. Most of the analysis to date has taken the form of ethnographic research and case studies, often with a focus on the question of whether the community would be more contented if the police better reflected the demographics of the areas being policed. The President's Commission on Law Enforcement argued that minority officers were more sensitive to needs of minority citizens and therefore were better able to serve as role models for improved police-community interactions. ${ }^{9}$ A host of studies have sought to test this view, with mixed results. Nicholas Alex concluded that African-American officers were more likely to challenge existing police behavioral stereotypes than white officers. ${ }^{10}$ Eugene Groves and Peter Rossi, on the basis of interviews of 391 white and 124 black officers who worked in predominantly black districts in 13 major cities, found that virtually all officers believed that black communities are either hostile or indifferent to law enforcement, although black officers tended to view black neighborhoods as less hostile than did white officers. ${ }^{11}$ The authors also concluded that black officers formed assessments of black neighborhoods that were more closely related to actual differences in community characteristics than did white officers. Scott Decker and Russell Smith analyzed a 1968 survey of citizen attitudes about public-sector services including police in 14 large cities and found that it gave modest support to the view that more black police meant higher satisfaction by black citizens. ${ }^{12}$

But Samuel Walker and Lawrence Sherman found no empirical support for the argument that increasing the number of minority officers improved police-community relations. ${ }^{13}$ Sherman also suggested that early occupational socialization experiences and specific career events were more predictive of

\footnotetext{
${ }^{7}$ James Q. Wilson, Varieties of Police Behavior: The Management of Law and Order in Eight Communities (1968); Knapp Comm'n, The Knapp Commission Report on Police Corruption (1972); James Morton, Bent Coppers: A Survey of Police Corruption (1993).

${ }^{8}$ Eric H. Monkkonen, History of Urban Police, in Tonry \& Morris eds., Modern Policing, supra note 4.

${ }^{9}$ President's Comm'n on Law Enforcement and Admin. Justice, Task Force Report: The Police (1968).

${ }^{10}$ Nicholas Alex, Black in Blue: A Study of the Negro Policeman (1969).

${ }^{11}$ Eugene W. Groves \& Peter H. Rossi, Police Perceptions of a Hostile Ghetto, 13 Am. Behav. Sci. 727 (1970).

${ }^{12}$ Scott H. Decker \& Russell L. Smith, Police Minority Recruitment: A Note on Its Effectiveness in Improving Black Evaluations of the Police, 8 J. Crim. Just. 387 (1980).

${ }^{13}$ Samuel Walker, A Critical History of Police Reform: The Emergence of Professionalism (1977); Lawrence W. Sherman, Causes of Police Behavior: The Current State of Quantitative Research, 17 J. Res. Crime \& Delinq. 69 (1980).
} 
police officer's attitudes toward communities than was race. Using data from a self-administered survey of 2,800 Los Angeles patrol officers in 1992, James Lasley reached virtually the same conclusion: race and gender "did not predict the extent to which a police officer will favor or oppose closer contact with citizens," and "police officer attitudes toward the community are more likely a product of occupational socialization than demographic background." 14

Although these studies are immensely useful in exploring police and community perceptions, virtually no work has provided systematic quantitative evidence of the impacts of the race of police officers on tangible social outcomes such as reductions in crime or patterns of arrest. ${ }^{15}$ The lone exception of which we are aware is by John Lott, ${ }^{16}$ who makes the claim that female and minority police are less effective at reducing crime on average than white male police. ${ }^{17}$

In this paper, we first develop a simple model for analyzing the impact of race on police and the communities they serve, allowing for the possibility of false arrests, different standards of guilt for making arrests within and

\footnotetext{
${ }^{14}$ James R. Lasley, Ethnicity, Gender, and Police-Community Attitudes, 75 Soc. Sci. Q. 85, 95-96 (1994).

${ }^{15}$ A separate economic literature documents the generally positive impact of affirmative action policies on the job opportunities of blacks (Orley Ashenfelter, James Heckman, \& James Joseph, Measuring the Effect of an Antidiscrimination Program, in Evaluating the Labor Market Effects of Social Programs (Orley Ashenfelter \& James Blum eds. 1974); Charles Brown, Black-White Earnings Ratios since the Civil Rights Act of 1964: The Importance of Labor Market Dropouts, 99 Q. J. Econ. 31 (1984); James J. Heckman \& Kenneth I. Wolpin, Does the Contract Compliance Program Work? An Analysis of Chicago Data, 29 Indus. \& Lab. Rel. Rev. 544 (1976); Jonathan S. Leonard, The Impact of Affirmative Action on Employment, 2 J. Lab. Econ. 439 (1984); Jonathan S. Leonard, The Impact of Affirmative Action Regulation and Equal Employment Law on Black Unemployment, 4 J. Econ. Persp. 47 (1990); William M. Rodgers III \& William E. Spriggs, The Effect of Federal Contractor Status on Racial Differences in Establishment-Level Employment Shares: 1979-1992, 86 Am. Econ. Rev. 290 (1996)), but without a focus on policing.

${ }^{16}$ John R. Lott, Jr., Does a Helping Hand Put Others at Risk? Affirmative Action, Police Departments, and Crime, 38 Econ. Inquiry 239 (2000).

${ }^{17}$ Our paper is also related to the existing scholarship on the effectiveness of police in fighting crime (for example, Samuel Cameron, The Economics of Crime Deterrence: A Survey of Theory and Evidence, 41 Kyklos 301 (1988); Thomas B. Marvell \& Carlisle E. Moody, Specification Problems, Police Levels, and Crime Rates, 34 Criminology 609 (1996); Steven D. Levitt, Using Electoral Cycles in Police Hiring to Estimate the Effect of Police on Crime, 87 Am. Econ. Rev. 270 (1997)), but only tangentially. That literature attempts to determine how much crime is expected to decrease in response to an exogeneous increase in the size of the police force. The analysis of this current paper is (1) concerned with arrest rates rather than crime rates and (2) focused on differences by race of police, rather than absolute magnitudes. The primary focus in that literature has been in distinguishing correlation and causality. Because we examine relative impacts of white and nonwhite police in the current analysis, the endogeneity problem may be less important, unless hiring of white and nonwhite police responds differentially to changes in crime. As noted elsewhere in this paper, the fact that we are limited to the analysis of arrest rates limits our ability to draw normative conclusions from our empirical results (see, for example, Robert E. McCormick \& Robert D. Tollison, Crime on the Court, 92 J. Pol. Econ. 223 (1984)).
} 
across racial lines, and police corruption. As the model demonstrates, different patterns of arrests and crime provide evidence about how race influences policing.

We then analyze empirically the relationship between minority representation in policing and arrest rates. The analysis combines publicly available city-level Federal Bureau of Investigation (FBI) data on crime and arrest rates and data on the racial composition of municipal police departments compiled over the last 20 years by the Equal Employment Opportunity Commission (EEOC). The EEOC data set is far superior in both the breadth of cities covered and the number of years for which data are available relative to data sets used in earlier studies of minority policing. ${ }^{18}$ While aggregated statistics have been published by the EEOC, the city-level data have not previously been exploited for scholarly research.

We find evidence across a wide range of crime categories that an increase in the number of white police is associated with more arrests of minorities but little change in white arrests. Conversely, an increase in minority officers is associated with more white arrests but not more minority arrests. The magnitude of our results is substantial. For the mean city in our sample, reallocating police from random assignment by race to an assignment that maximizes same-race policing (holding the number and racial composition of the police constant) is predicted to reduce arrests by more than 15 percent.

There are a number of possible explanations for this relationship between racial composition of the police and arrest patterns. First, same-race police may engender greater community cooperation, which makes them more effective in solving crimes. This increased deterrence might be associated with a decline in the total number of crimes and arrests. ${ }^{19}$ Second, same-race police might make fewer false arrests. Both of these first two channels suggest that same-race policing is welfare improving. Third, same-race police may require a higher standard of guilt before making an arrest. This explanation has ambiguous welfare implications, which depend on the relative costs and benefits of the marginal arrest. Fourth, same-race policing may foster corruption, reducing social welfare. Finally, the link between the race of police officers and arrests may not be causal but, rather, driven by unobserved factors such as the strength of the minority community. To distinguish between these competing hypotheses, one must understand the simultaneous impact of the race of police on crime. Unfortunately, our initial forays into explicating this relationship have been inconclusive. The primary difficulty is that, unlike

\footnotetext{
${ }^{18}$ Samuel Walker, Employment of Black and Hispanic Police Officers: Trends in the 50 Largest Cities, 11 Rev. Applied Urb. Res. 1 (1983); E. Hochstedler \& J. Conley, Explaining Underrepresentation of Black Officers in City Police Agencies, 6 J. Police Sci. \& Admin. 168 (1986); and Larry D. Stokes \& James F. Scott, Affirmative Action Policy Standard and Employment of African Americans in Police Departments, 17 W. J. Black Stud. 135 (1993).

${ }^{19}$ McCormick \& Tollison, supra note 17.
} 


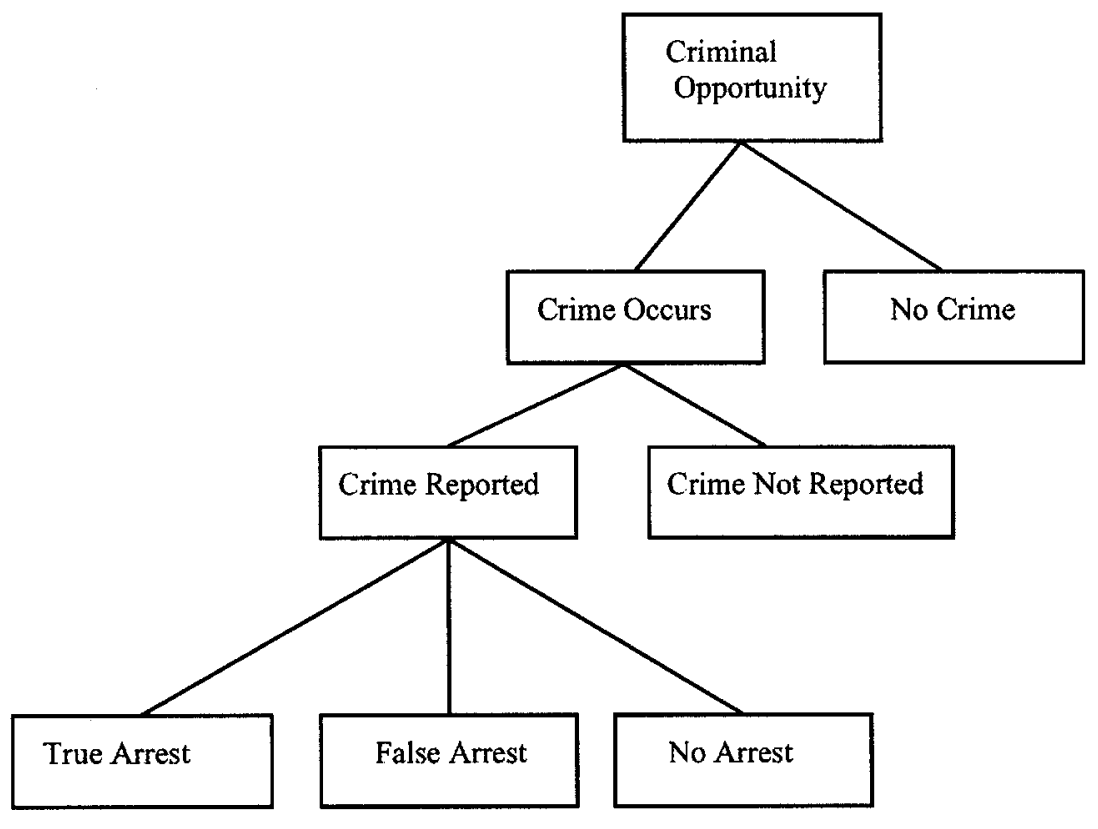

FIGURE 1.-Timing of the model

arrest data, crime data are not available by race since the race of the offender is often not observed.

The outline of the paper is as follows. Section I develops the theoretical model. Section II describes the data sets and empirical strategy in greater detail. Section III presents the empirical results. Section IV suggests a variety of approaches for understanding the underlying causes of the results in Section III. Section V concludes.

\section{A Stylized Model of Race in Policing}

In this section, we model the interaction between police, criminals, and the community, allowing for police practices to affect both criminal behavior and the decision of victims to report crimes to the police. Also included implicitly in the modeling is the possibility of either false arrests or police corruption. After presenting the model, we explore the implications of the model with respect to the racial composition of police forces and the impact on arrest patterns, crime rates, and victim reporting rates.

The timing of the actions in the model is detailed in Figure 1. First, a criminal opportunity arises and the potential criminal decides whether or not 
to commit the crime ${ }^{20}$ If the offense is committed, the victim chooses whether or not to report the crime to the police. If the crime is not reported, the criminal goes unpunished. If the crime is reported to the police, the crime is investigated, leading to either the arrest of the criminal (a "true" arrest), the arrest of someone other than the true offender (a "false" arrest), or no arrest.

Race enters the model through its impact on the likelihood that a true or false arrest is made, conditional on a crime being reported. The frequency with which a reported crime results in either a true or false arrest is assumed to depend on whether the race of the victim and the investigating officer are the same or different. ${ }^{21}$ When the race of the victim and the officer are the same, it is possible that there is greater community cooperation in helping to solve the crime or more knowledge of the community and its cultural norms on the part of the officer, leading to a higher frequency of successful arrests and perhaps fewer false arrests. On the other hand, it may be the case that police have different standards for making arrests within and across racial lines owing to tastes or prejudice. It is frequently alleged, for instance, that white officers disproportionately single out nonwhite youths for harassment. Also, collusive agreements between criminal organizations and police may be easier to enforce within a racial group, resulting in fewer successful arrests owing to corruption.

Denoting the likelihood of a true arrest as $T$ and a false arrest as $F$, the relationship between race and arrest probabilities is expressed formally as

$$
T_{i}= \begin{cases}T_{i}\left(P_{\mathrm{w}}, P_{\mathrm{n}}\right) & \text { if } R=1, \\ 0 & \text { if } R=0\end{cases}
$$

and

$$
F_{i}= \begin{cases}F_{i}\left(P_{\mathrm{w}}, P_{\mathrm{n}}\right) & \text { if } R=1, \\ 0 & \text { if } R=0\end{cases}
$$

where the subscript $i$ refers to the race of the criminal, $R$ is an indicator variable equal to one if the crime is reported to the police and zero otherwise, and $P_{\mathrm{w}}$ and $P_{\mathrm{n}}$ are the number of white and nonwhite police officers per capita, respectively. When $R=0$, both $T$ and $F$ are zero-that is, no arrest will be made. When $R=1, T$ and $F$ are positive. Increasing the number of police $\left(P_{\mathrm{w}}\right.$ and $\left.P_{\mathrm{n}}\right)$ is likely to have a positive impact on true arrests but may have an ambiguous effect on the number of false arrests. White and nonwhite

\footnotetext{
${ }^{20}$ For simplicity, we restrict model development to the case of a single criminal faced with the choice of committing a single crime. Extending the model to crimes committed by multiple offenders does not alter the logic, nor does allowing for repeat offenses.

${ }^{21}$ There is nothing intrinsic to this modeling structure that limits consideration to racial differences. The model is equally applicable to consideration of systematic effects of ethnicity, gender, or class differences.
} 
police may have different effects on $T$ and $F$, and the effects may vary across the race of the victims.

Whether or not a victim reports a crime to the police is assumed to be a function of the likelihood that reporting the crime leads to either a true or false arrest that, from equations (1) and (2), depends on the size and racial composition of the police force: ${ }^{22}$

$$
R_{i}=R_{i}\left(T_{i}\left(P_{\mathrm{w}}, P_{\mathrm{n}}\right), F_{i}\left(P_{\mathrm{w}}, P_{\mathrm{n}}\right)\right)
$$

where the $i$ subscript refers to the race of the victim and it is assumed that $\partial R_{i} / \partial T_{i}>0$ and $\partial R_{i} / \partial F_{i}<0$. A greater likelihood of a successful arrest increases the incentive to report the crime by increasing the likelihood that a victim recovers lost property or by providing utility in the form of an increased sense of security or retribution. A greater chance of false arrest does not directly benefit the victim, and false arrests here serve as a proxy for the degree of harassment of the community by the police. If false arrests are common, police-community relations are likely to be strained, which leads to less crime reporting. ${ }^{23}$ Note that tastes for white or nonwhite police play no role in the crime victim's decision to report in this model but that because arrest rates are a function of the racial composition of the police force, the race of police can have an indirect impact on victim reporting behavior.

Criminals in the model are risk-neutral expected utility maximizers whose decisions about whether to commit crimes depend on the likelihood of a true arrest, which is a function of victim reporting rates and true arrests conditional on victim reporting: ${ }^{24}$

$$
C_{i}=C_{i}\left(R_{i}\left(P_{\mathrm{w}}, P_{\mathrm{n}}\right) \times T_{i}\left(P_{\mathrm{w}}, P_{\mathrm{n}}\right)\right),
$$

where $C_{i}$ reflects crimes committed by criminals of race $i$. The product of $R \times T$ is the likelihood with which a criminal will be arrested for committing a particular crime.

\footnotetext{
${ }^{22}$ While not critical to the model, for simplicity we assume that the race of the victim and the race of the criminal are the same. Data from the National Crime Victimization Survey roughly support this assumption. White victims of violent crime with a single offender are four times more likely to report that the offender is white than black. Black victims are eight times as likely to describe the offender as black rather than white.

${ }^{23}$ If having more police increases the likelihood of true arrests and decreases the chance of false arrests, then reporting rates will unambiguously increase. Although a priori unlikely, it is at least theoretically possible that a decline in the reporting rate would be observed as police are added if an increase in false arrests overwhelmed the effects of an increase in true arrests. In practice, however, the responsiveness of reporting rates to true arrests is likely to be greater than that of false arrests since an increase in true arrests carries a direct benefit to the crime victim, whereas false arrests have only indirect effects.

${ }^{24}$ Criminal decisions are not affected by the frequency of false arrests in this model, although in the real world it may be the case that a longer criminal record makes it more likely that a false arrest wrongly results in punishment for a crime that the criminal did not commit. This impact, however, is likely to be only of second-order importance.
} 
On the basis of equations (1)-(4), the total number of arrests can be expressed as

$$
A_{i}=C_{i} \times R_{i} \times\left(T_{i}+F_{i}\right),
$$

where $A_{i}$ reflects the total number of arrests of suspects of race $i$ and the other variables are as described above, but with functional dependencies omitted. The total number of arrests is equal to the number of reported crimes $(C \times R)$ multiplied by the combined arrest rate for both true and false arrests per reported crime $(T+F)$.

Having laid out the elements of the model, it is now possible to examine the impact of changes in the number of officers on the measures of interest and, in particular, focus on the differential impacts of white and nonwhite police. Because the number of arrests is the crime measure for which the best data are available by race, we focus the analysis on equation (5). Taking the partial derivative of equation (5) with respect to both nonwhite and white police yields

$$
\begin{aligned}
\frac{\partial A_{i}}{\partial P_{\mathrm{n}}}-\frac{\partial A_{i}}{\partial P_{\mathrm{w}}}= & R_{i}\left(T_{i}+F_{i}\right)\left(\frac{\partial C_{i}}{\partial P_{\mathrm{n}}}-\frac{\partial C_{i}}{\partial P_{\mathrm{w}}}\right)+C_{i}\left(T_{i}+F_{i}\right)\left(\frac{\partial R_{i}}{\partial P_{\mathrm{n}}}-\frac{\partial R_{i}}{\partial P_{\mathrm{w}}}\right) \\
& +C_{i} R_{i}\left(\frac{\partial T_{i}}{\partial P_{\mathrm{n}}}-\frac{\partial T_{i}}{\partial P_{\mathrm{w}}}\right)\left(\frac{\partial F_{i}}{\partial P_{\mathrm{n}}}-\frac{\partial F_{i}}{\partial P_{\mathrm{w}}}\right),
\end{aligned}
$$

where equation (6) is the marginal difference in the impact on arrests of suspects of race $i$ from an increase in the number of nonwhite officers compared to white officers. Four factors help to determine this relationship, which correspond to the four terms in equation (6). The first term reflects the fact that reductions in crime, ceteris paribus, will lead to fewer arrests. Thus, if police of one race are more effective in deterring crime by criminals of race $i$, then adding police of that race may result in fewer arrests. The second term captures changes in reporting behavior of victims; for example, if more crimes are reported when there are more minority police, then the presence of minority police will be associated with more arrests. The third and fourth terms represent the direct changes in arrests owing to differential true arrests and false arrests per crime across officers of different races. In the empirical section that follows, reduced-form variations on equation (6) are estimated. We are unable to separately identify the different channels through which racial composition of the police force affect arrest patterns using the data that we have.

If race-specific estimates of criminal activity were available, one would also want to directly estimate the relationship between crime by race and the racial composition of the police force: 


$$
\frac{\partial C_{i}}{\partial P_{\mathrm{n}}}-\frac{\partial C_{i}}{\partial P_{\mathrm{w}}}=\frac{d C_{i}}{d T}\left(\frac{\partial T_{i}}{\partial P_{\mathrm{n}}}-\frac{\partial T_{i}}{\partial P_{\mathrm{n}}}\right)+\frac{d C_{i}}{d R}\left(\frac{\partial R_{i}}{\partial P_{\mathrm{n}}}-\frac{\partial R_{i}}{\partial P_{\mathrm{n}}}\right) .
$$

Unfortunately, data on the race of the offender are available only when a crime is solved by arrest. Often the victim does not observe the race of the criminal in crimes such as auto theft or burglary. For those crimes in which a victim does identify the race of the suspect, this information is not systematically collected and reported in the available data sets. In Section IV, we discuss indirect approaches to identifying a differential impact of police on crime as a function of race.

\section{Data Sources and Estimation Approach}

The data set used in this paper is a panel of data containing the 122 U.S. cities with population greater than 100,000 as of the year 1975. Panel data, with city fixed effects and time dummies included as controls, are less likely to be adversely affected by unobserved heterogeneity than would crosssectional data from cities in a given year. The limiting factor on our sample is data on the racial composition of municipal police forces, taken from the EEO-4 survey of state and local governments conducted annually by the EEOC since 1973. Working in concert with the technical staff of the EEOC, we have obtained access to data for the years 1977, 1981, 1984, 1986, 1989, and 1993. For each department of the local government, the racial and gender composition of the work staff is reported by functional category (for example, protective services, officials and administrators, administrative support, and professionals). ${ }^{25}$ Although greater detail on race is available in the data, we limit our analysis in this paper to the broad classifications of white and nonwhite. The primary motivation for doing so is concern over the lack of comparability of the definition of Hispanic across data sources. ${ }^{26}$ In some specifications, cities with Hispanic populations greater than 10 percent using the census definition are eliminated as a check on the sensitivity of the results.

We focus our analysis on those members of police departments whose job function is protective service. This definition captures patrol officers, excluding both officers assigned to desk duties as well as supervisors. This categorization is closely related to, but somewhat more restrictive than, the

\footnotetext{
${ }^{25}$ Given the remarkable scope and detail of this data set, it is surprising that it has not been used previously, to the best of our knowledge, in any published academic work. In addition to the data we will use on the racial and gender composition of the workforce, there are also data on the breakdown of new hires, as well as salary information by race, sex, and job function.

${ }^{26}$ The EEOC requires employers to report demographic data on workers, with Hispanics treated as their own category, separate from white and black. In the U.S. census, Hispanic status is treated as an ethnicity rather than a race-that is, each individual is assigned both a racial classification and is denoted Hispanic/non-Hispanic. Further complicating comparisons is the fact that the definition of Hispanic has changed over time in the census. Moreover, prior to 1980 , Hispanics are not separately broken out in FBI arrest data.
} 
FBI's measure of sworn police officers. For the cities in our sample, the raw correlation between sworn police officers, as reported in the FBI's Uniform Crime Reports (UCR), and the EEOC measure is .92. The EEOC-reported value is on average 18 percent smaller than the FBI measure.

Figure 2 shows the number of police in the 10 largest cities for which we have complete data from the EEOC in our 6 years of data over the period from 1977 through 1993 and shows comparable data from the Uniform Crime Reports and yet another source of police data, the Law Enforcement Management and Administrative Statistics (LEMAS), collected by the Department of Justice in 1987, 1990, and $1997 .{ }^{27}$ The figure reveals that both the UCR and LEMAS figures, which are based on a more comprehensive count of police officers, are uniformly higher than the EEOC figures, but the patterns for the different data sets are similar. Notably, we see that while the total number of police in the EEOC data was rather stable for the first 6 years of our data, the percentage of nonwhite officers has increased steadily, from 21.4 percent in 1977 to 31.2 in 1986 to 38.4 percent in 1993. The LEMAS data also reveal an increase in nonwhite police from 29.5 percent in 1987 to 38.1 percent in 1993.

The only crime variable for which a long panel of racial breakdowns by city is available is arrests. These data are collected by the FBI and are available disaggregated by crime category on an annual basis. ${ }^{28}$ Including a relevant set of control variables, the impact of white and nonwhite officers on white and nonwhite arrests can consequently be directly estimated.

The set of covariates included in the regressions is constrained by the lack of data available on an annual basis at the city level. While some variables, such as city population and the presence of a black mayor, are available annually for cities, in other cases compromises must be made. We attempt to deal with these data limitations in three ways. First, where annual data for larger geographic areas exist, we use the most disaggregated data series available. Thus, Standard Metropolitan Statistical Area-level unemployment rates, state per capita income, and state measures of the age distribution are included as regressors. Second, where city-level measures are critical, as with the percentage of black inhabitants, we linearly interpolate between decennial censuses. Finally, as a substitute for effective covariates, we include year dummies, city fixed effects, and, in some specifications, region-year inter-

\footnotetext{
${ }^{27}$ The UCR and LEMAS numbers represent full-time sworn officers, while the EEOC numbers represent officers whose job function is protective service. The 10 cities (with their ranking by size of police force in 1993 in parentheses) are Chicago (2), Los Angeles (3), Detroit (6), Phoenix (10), San Diego (12), San Jose (24), Miami (27), Buffalo (32), Minneapolis (37), and Jersey City (38).

${ }^{28}$ Although the race of the arresting officer is not included in the arrest data, we can still estimate the impact on arrests of adding an additional officer of a particular race using citylevel data. Given the endogenous assignment of officers to patrol beats on the basis of race, trying to estimate the impact of the race of the arresting officer through the use of individuallevel data would likely raise more difficulties than it would solve.
} 


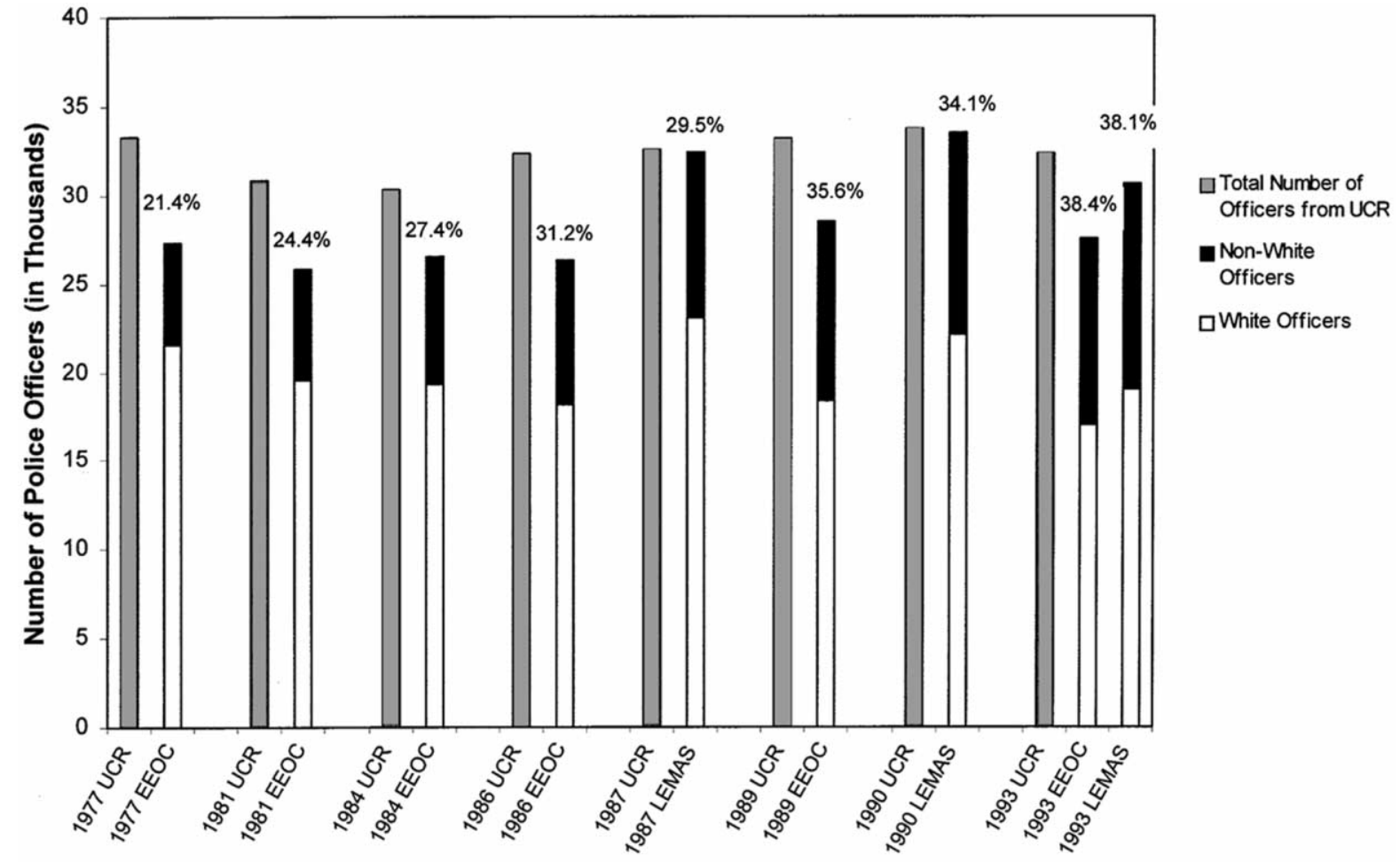

FIGURE 2.-Number of police officers in 10 cities for selected years from Uniform Crime Reports, Equal Employment Opportunity Commission, and Law Enforcement Management and Administrative Statistics data. 
TABLE 1

Summary STATistics

\begin{tabular}{|c|c|c|c|}
\hline Variable & $\begin{array}{c}\text { Mean } \\
(1)\end{array}$ & $\begin{array}{l}\text { SD } \\
(2)\end{array}$ & $\begin{array}{c}\text { SD } \\
\text { (Without } \\
\text { City and Year } \\
\text { Fixed Effects) } \\
\text { (3) }\end{array}$ \\
\hline Violent crime arrests per capita (whites) & .0026 & .0018 & .0007 \\
\hline Violent crime arrests per capita (nonwhites) & .0085 & .0038 & .0016 \\
\hline Property crime arrests per capita (whites) & .0090 & .0043 & .0015 \\
\hline Property crime arrests per capita (nonwhites) & .0174 & .0089 & .0028 \\
\hline Drug crime arrests per capita (whites) & .0048 & .0036 & .0020 \\
\hline Drug crime arrests per capita (nonwhites) & .0074 & .0054 & .0031 \\
\hline Total arrests per capita (whites) & .0524 & .0212 & .0099 \\
\hline Total arrests per capita (nonwhites) & .0872 & .0466 & .0186 \\
\hline White police per capita $(\times 1,000)$ & 1.70 & .69 & .18 \\
\hline Nonwhite police per capita $(\times 1,000)$ & .46 & .33 & .14 \\
\hline White firefighters per capita $(\times 1,000)$ & .94 & .43 & .15 \\
\hline Nonwhite firefighters per capita $(\times 1,000)$ & .19 & .15 & .07 \\
\hline Violent crime per capita & .013 & .007 & .002 \\
\hline Property crime per capita & .076 & .019 & .010 \\
\hline Percent white (city population) & .643 & .147 & .023 \\
\hline Percent black (city population) & .250 & .163 & .019 \\
\hline Percent other (city population) & .106 & .089 & .022 \\
\hline Black as a fraction of all nonwhite & .67 & .26 & .03 \\
\hline Black mayor & .194 & .395 & .226 \\
\hline SMSA unemployment rate & .068 & .022 & .012 \\
\hline State income per capita (1993\$) & 19,430 & 2,828 & 704 \\
\hline City population & $1,711,032$ & $2,242,702$ & 100,345 \\
\hline Percent state population aged $0-17$ & .274 & .025 & .005 \\
\hline Percent state population aged $18-24$ & .123 & .011 & .003 \\
\hline Percent state population aged $25-44$ & .296 & .029 & .003 \\
\hline
\end{tabular}

Note.-Data correspond to 6 years of observations $(1977,1981,1984,1986,1989$, and 1993) for 122 U.S. cities with population greater than 100,000 in 1975 . Because of missing data on arrests and crime rates, the actual number of observations varies between 586 and 600 . City population breakdowns are linearly interpolated between decennial censuses. SMSA = Standard Metropolitan Statistical Area. The reported means and standard deviations (SDs) are weighted by city population.

actions using the nine U.S. census regions. To the extent that other (unmeasured) demographic and socioeconomic factors exhibit a similar pattern, the use of these indicator variables will reduce any omitted-variable bias from this source. Furthermore, we test the sensitivity of the results to the inclusion of city-level trends that account for any differential trends in variables across cities because of unobserved factors.

Summary statistics for all of the variables used in the analysis are presented in Table 1. The table also shows the standard deviations of the raw variables, as well as standard deviations with city and year fixed effects removed. Per capita arrest rates of nonwhites are substantially higher than per capita arrests of whites for all of the offense categories we examine. Conversely, police and firefighters are disproportionately white. On average, whites make up 
roughly 80 percent of both the police and firefighters in our sample, despite the fact that only 63 percent of city residents are white. Comparing the raw standard deviations (column 2) to the standard deviations after city and year fixed effects have been removed (column 3), we find that approximately 40-60 percent of the variation in the crime and police variables remains. In contrast, for many of the other variables such as city population, demographic measures, and the age distribution, 90 percent of the variation is eliminated by the city fixed effects and year dummies. Thus, in the analysis that follows, some caution must be given to interpreting coefficients on the latter set of variables since so little variation remains to identify the parameters after removing city fixed effects and year dummies.

In studying the link between police and arrests, endogeneity is an important concern. As crime increases, a frequent public policy response is to add police, leading to simultaneity bias. We deal with this issue in two ways. First, the police variables are once-lagged in the regression to eliminate any contemporaneous feedback from crime increases to more police hiring. If crime shocks were uncorrelated, using once-lagged police would eliminate endogeneity. In practice, however, crime shocks are likely to be serially correlated, so this fix may be incomplete. The second approach is to find an instrumental variable for police. Steven Levitt, for instance, uses the timing of mayoral and gubernatorial elections. ${ }^{29}$ That approach is not useful here, because the hiring of white and nonwhite officers is equally affected by elections, and thus the instrument has no power to identify the parameters of interest in the current context. Instead, we use the size and racial composition of the fire department as an instrument for white and nonwhite police, under the assumption that changes in fire department staffing are unrelated to changes in crime but are associated with changes in the police force. A final point worth noting with respect to endogeneity is that the focus of the paper is not on the absolute impact of police on arrests but rather on the relative impact of white and nonwhite officers. To the extent that the coefficient estimates on white and nonwhite officers are similarly affected by any endogeneity bias, their difference will nonetheless be unbiased.

\section{Results of Estimation}

Table 2 presents the results from estimation of the relationship between arrest patterns by race of suspect and the racial composition of the police force. The specifications estimated are of the form

$$
\begin{aligned}
\text { White Arrests }_{c t}= & \beta_{1} \text { White Police }_{c t-1}+\beta_{2} \text { Nonwhite Police }_{c t-1} \\
& +X_{c t} \Gamma+\gamma_{c}+\lambda_{t}+\varepsilon_{c t}
\end{aligned}
$$

\footnotetext{
${ }^{29}$ Levitt, supra note 17.
} 
and

$$
\begin{aligned}
\text { Nonwhite Arrests }_{c t}= & \beta_{3} \text { White Police }_{c t-1}+\beta_{4} \text { Nonwhite Police }_{c t-1} \\
& +X_{c t} \Phi+\gamma_{c}+\lambda_{t}+\varepsilon_{c t},
\end{aligned}
$$

where $c$ indexes cities; $t$ corresponds to years; and $X$ is the vector of economic, socioeconomic, and demographic controls described above. The arrest variables are arrests in a given crime category per member of the racial classification (for example, violent crime arrests of nonwhites per nonwhite resident). The police variables are per capita using the city population as the denominator. This specification assumes that any given individual's probability of arrest is a linear function of the number of white and nonwhite police per capita (all of the results are also robust to estimation in log units). One advantage of this choice of specification is that the interpretation of the $\beta$ coefficients does not depend on racial composition of a city's population. The literal interpretation of the $\beta$ coefficients is the change in the number of arrests when one officer of a given race is added to the police force. Our primary focus is on the difference in $\beta$ by race of police - that is, how much do arrests of suspects of a given race change as a function of the racial composition of the police force, holding the total number of police constant? The $\gamma$ and $\lambda$ terms represent city fixed effects and year dummies, respectively.

The eight columns of Table 2 correspond to results by race of arrestee for four different arrest categories: total arrests (including the three other categories examined, as well as public order offenses, prostitution, drunk driving, and a wide range of other generally minor crimes), property crime (burglary, larceny, and auto theft), violent crime (murder, rape, robbery, and aggravated assault), and drug offenses (both possession and distribution). Almost twothirds of all arrests are for offenses not covered by the last three categories. Year dummies and city fixed effects are included in the regressions but are not reported in the table. All specifications are estimated using weighted least squares with weights proportional to city population.

We turn our attention first to the top four rows of Table 2, which present the parameters of primary interest. The top two rows contain estimates of the change in the number of arrests of each type with respect to the number of white police officers. The third and fourth rows present that same coefficient for nonwhite officers. Comparing the coefficients in the top four rows of the first column, the addition of white police is associated with a statistically insignificant .13 increase in the number of white total arrests per capita, whereas additional nonwhite officers are associated with a statistically significant increase of 18.5 arrests of white suspects. Our primary interest is in the difference between these two coefficients rather than the levels themselves. Therefore, the bottom row of the table reports the $p$-value from a $t$ test of the null hypothesis that the impact of white and nonwhite officers is the same. This hypothesis of equality is rejected. 
TABLE 2

Racial Composition of the Police Force and the Pattern of White and Nonwhite Arrests

\begin{tabular}{|c|c|c|c|c|c|c|c|c|}
\hline \multirow[b]{2}{*}{ VARIABLE } & \multicolumn{2}{|c|}{ Total Arrests } & \multicolumn{2}{|c|}{ Property Arrests } & \multicolumn{2}{|c|}{ Violent ARrests } & \multicolumn{2}{|c|}{ Drug Arrests } \\
\hline & $\begin{array}{l}\text { White } \\
\text { (1) }\end{array}$ & $\begin{array}{c}\text { Nonwhite } \\
\text { (2) }\end{array}$ & $\begin{array}{l}\text { White } \\
\text { (3) }\end{array}$ & $\begin{array}{c}\text { Nonwhite } \\
\text { (4) }\end{array}$ & $\begin{array}{l}\text { White } \\
(5)\end{array}$ & $\begin{array}{c}\text { Nonwhite } \\
\text { (6) }\end{array}$ & $\begin{array}{l}\text { White } \\
\text { (7) }\end{array}$ & $\begin{array}{c}\text { Nonwhite } \\
(8)\end{array}$ \\
\hline White police & $\begin{array}{r}.13 \\
(2.67)\end{array}$ & $\begin{array}{c}9.16 \\
(4.54)\end{array}$ & $\begin{array}{l}.26 \\
(.43)\end{array}$ & $\begin{array}{c}.80 \\
(.84)\end{array}$ & $\begin{array}{c}-.32 \\
(.28)\end{array}$ & $\begin{array}{l}1.57 \\
(.51)\end{array}$ & $\begin{array}{c}-.64 \\
(.50)\end{array}$ & $\begin{array}{c}-.06 \\
(.97)\end{array}$ \\
\hline Nonwhite police & $\begin{array}{l}18.50 \\
(3.96)\end{array}$ & $\begin{array}{c}-7.53 \\
(8.27)\end{array}$ & $\begin{array}{l}1.05 \\
(.63)\end{array}$ & $\begin{array}{c}-2.72 \\
(1.02)\end{array}$ & $\begin{array}{l}1.21 \\
(.50)\end{array}$ & $\begin{array}{c}.38 \\
(.62)\end{array}$ & $\begin{array}{l}2.21 \\
(.69)\end{array}$ & $\begin{array}{c}.56 \\
(1.57)\end{array}$ \\
\hline Black population/nonwhite population & $\begin{array}{c}-.071 \\
(.034)\end{array}$ & $\begin{array}{l}.130 \\
(.050)\end{array}$ & $\begin{array}{c}-.004 \\
(.005)\end{array}$ & $\begin{array}{l}.039 \\
(.007)\end{array}$ & $\begin{array}{c}-.005 \\
(.004)\end{array}$ & $\begin{array}{l}.010 \\
(.004)\end{array}$ & $\begin{array}{l}.006 \\
(.007)\end{array}$ & $\begin{array}{c}.029 \\
(.012)\end{array}$ \\
\hline $\log ($ city population) & $\begin{array}{c}-.011 \\
(.008)\end{array}$ & $\begin{array}{c}-.031 \\
(.014)\end{array}$ & $\begin{array}{l}.0008 \\
(.0002)\end{array}$ & $\begin{array}{c}-.0036 \\
(.0025)\end{array}$ & $\begin{array}{c}-.0002 \\
(.0006)\end{array}$ & $\begin{array}{c}-.0050 \\
(.0012)\end{array}$ & $\begin{array}{c}-.0004 \\
(.0015)\end{array}$ & $\begin{array}{c}-.0007 \\
(.0020)\end{array}$ \\
\hline Black mayor & $\begin{array}{c}-.0088 \\
(.0049)\end{array}$ & $\begin{array}{c}-.0280 \\
(.0096)\end{array}$ & $\begin{array}{l}.0003 \\
(.0005)\end{array}$ & $\begin{array}{l}.0004 \\
(.0007)\end{array}$ & $\begin{array}{c}-.0002 \\
(.0002)\end{array}$ & $\begin{array}{c}-.0008 \\
(.0005)\end{array}$ & $\begin{array}{l}.0002 \\
(.0005)\end{array}$ & $\begin{array}{c}-.0011 \\
(.0008)\end{array}$ \\
\hline SMSA unemployment rate & $\begin{array}{c}-.180 \\
(.074)\end{array}$ & $\begin{array}{c}-.225 \\
(.137)\end{array}$ & $\begin{array}{c}-.009 \\
(.009)\end{array}$ & $\begin{array}{l}.015 \\
(.014)\end{array}$ & $\begin{array}{c}-.004 \\
(.004)\end{array}$ & $\begin{array}{c}-.012 \\
(.009)\end{array}$ & $\begin{array}{c}-.010 \\
(.012)\end{array}$ & $\begin{array}{c}-.022 \\
(.021)\end{array}$ \\
\hline Percent state population aged $0-17$ & $\begin{array}{c}.411 \\
(.196)\end{array}$ & $\begin{array}{c}-.273 \\
(.335)\end{array}$ & $\begin{array}{l}.050 \\
(.033)\end{array}$ & $\begin{array}{c}-.010 \\
(.045)\end{array}$ & $\begin{array}{l}.033 \\
(.017)\end{array}$ & $\begin{array}{c}-.049 \\
(.026)\end{array}$ & $\begin{array}{l}.187 \\
(.034)\end{array}$ & $\begin{array}{l}.061 \\
(.057)\end{array}$ \\
\hline Percent state population aged $18-24$ & $\begin{array}{c}-.100 \\
(.306)\end{array}$ & $\begin{array}{r}-1.282 \\
(.684)\end{array}$ & $\begin{array}{l}.006 \\
(.047)\end{array}$ & $\begin{array}{c}-.101 \\
(.081)\end{array}$ & $\begin{array}{l}.074 \\
(.023)\end{array}$ & $\begin{array}{l}.005 \\
(.047)\end{array}$ & $\begin{array}{c}.272 \\
(.057)\end{array}$ & $\begin{array}{l}.121 \\
(.092)\end{array}$ \\
\hline Percent state population aged $25-44$ & $\begin{array}{c}-.307 \\
(.317)\end{array}$ & $\begin{array}{c}-.336 \\
(.518)\end{array}$ & $\begin{array}{l}.034 \\
(.049)\end{array}$ & $\begin{array}{c}.073 \\
(.078)\end{array}$ & $\begin{array}{c}.033 \\
(.024)\end{array}$ & $\begin{array}{c}.099 \\
(.056)\end{array}$ & $\begin{array}{l}.016 \\
(.058)\end{array}$ & $\begin{array}{c}-.002 \\
(.087)\end{array}$ \\
\hline State income per capita $\left(\times 10^{6}\right)$ & $\begin{array}{l}.016 \\
(.017)\end{array}$ & $\begin{array}{c}-.047 \\
(.421)\end{array}$ & $\begin{array}{l}.009 \\
(.023)\end{array}$ & $\begin{array}{c}-.014 \\
(.035)\end{array}$ & $\begin{array}{r}-.006 \\
(.012)\end{array}$ & $\begin{array}{c}-.031 \\
(.025)\end{array}$ & $\begin{array}{l}.063 \\
. .029)\end{array}$ & $\begin{array}{l}.096 \\
.053)\end{array}$ \\
\hline Adjusted $R^{2}$ & .780 & .831 & .857 & .894 & .826 & .800 & .727 & .636 \\
\hline$p$-Value: white police $=$ nonwhite police & $<.001$ & .098 & .32 & .010 & .012 & .19 & $<.010$ & .75 \\
\hline
\end{tabular}

Note. - Dependent variable (in per capita terms) is listed at the top of each column. Year dummies and city fixed effects are included in all regressions. The data set is a panel of 6 years of observations between 1977 and 1994 for all U.S. cities with a population greater than 100,000 in 1975. The police variables are once-lagged. The number of observations ranges between 586 and 600 because of occasional missing data. The $p$-values reported are from a $t$-test of the equality of the white and nonwhite skedasticity robust standard errors are in parentheses. 
The pattern of coefficients in the second column, corresponding to total arrests of nonwhites, is the reverse of that in the first column. Nonwhite arrests are positively related to the addition of more white officers but appear to decline with the addition of nonwhite officers. The null hypothesis of equality across these two coefficients, however, is only rejected at the .10 level.

Parallel results are presented for the other arrest categories in the top four rows of columns (3)-(8). The regularity of the results across arrest categories is striking. For all four arrests categories, white arrests increase more from the addition of a nonwhite officer than from the addition of a white officer. Similarly, except for drug arrests, nonwhite arrests always increase more from the addition of a white officer than from the addition of a nonwhite officer. The difference is statistically significant at the .05 level in four of the eight cases. In addition, comparing across rows rather than columns (that is, looking at whether adding officers of a given race increases arrests more within race or across race), in all eight instances the across-race effect is greater than the within-race effect. In other words, the general pattern is that more white police means more arrests of nonwhites, and more nonwhite police means more arrests of whites.

The differences between same-race and cross-race policing are substantively large. Consider the following alternative allocations of police: (1) assign police randomly by race, and (2) assign police to maximize samerace policing, holding the present number and racial composition of police officers constant. Evaluated at the sample means of our data, moving from the first allocation to the second allocation would involve shifting just over one-quarter of all police from cross-race to same-race policing. ${ }^{30}$ On the basis of the coefficients in Table 2, this reassignment of officers would be predicted to yield a decrease in total arrests of 16.0 percent and decreases of 10.4 , 17.1 , and 11.5 percent in property, violent, and drug arrests, respectively. ${ }^{31}$ These estimates are likely to be upper bounds on actual changes in arrests, both because minority officers may already be disproportionately assigned

\footnotetext{
${ }^{30}$ In our data set, whites are 78.7 percent of the police force and 64.3 percent of city residents. Thus, if police are randomly assigned by race, 64.3 percent of nonwhite police interactions (or 13.7 percent $(.213 \times .643)$ of total police-citizen interactions) will involve nonwhite officers and white citizens. If police are assigned to maximize same-race interactions, then nonwhite officers will interact only with nonwhite citizens, necessitating a shift of 13.7 percent of police interactions from nonwhite officer/white citizen to nonwhite officer/nonwhite citizen. An equal number of white officers will have to be shifted in the other direction, which means that 27.4 percent of officers will be reassigned. If nonwhites are more likely to be arrested than whites, then a smaller reassignment of officers is necessary.

${ }^{31}$ The prediction that the reassignment of police to increase same-race policing would lead to lower rates of arrest does not suggest that this reassignment would be desirable. Arrests can drop for good reasons (for example, more effective policing leads to less crime and hence fewer arrests, or less harassment of citizens leads to fewer arrests) or bad (the police are more corrupt or less vigilant, presumably leading to higher rates of crime).
} 
to minority neighborhoods in many cities and because perfect racial matching could never actually be achieved.

Estimates of the other covariates in the regressions appear generally reasonable and consistent with past research. The fraction of nonwhite residents that are black (as opposed to Asian or "other") is positively correlated with nonwhite arrests, which implies higher arrest rates of blacks than other minorities. ${ }^{32}$ This variable would not be expected to directly affect white arrests and with one exception is not statistically significant in the odd columns. City population is negatively related to arrest rates across all eight specifications. This result is consistent with both a study by Edward Glaeser and Bruce Sacerdote, which documents lower probabilities of arrest in big cities, and a study by Julie Cullen and Levitt, which finds that increasing crime rates are associated with urban flight. ${ }^{33}$ All else equal, therefore, cities with increasing populations tend to have decreasing crime rates. ${ }^{34}$ Arrest rates are generally lower when a black mayor holds office and, somewhat surprisingly, when unemployment rates are high. Income per capita appears to be positively related to drug arrests but is not statistically significantly related to any of the other categories. State age shares do not carry a consistent sign (the omitted category is the percent of the population over age 45). This is not particularly surprising given the limited variation in these measures that remains once city and year effects have been removed.

Sensitivity of the Estimates of Differential Impact of Same-Race and CrossRace Policing. Because the principal analysis of this paper is based not on the raw police coefficients themselves but rather on the differential between the coefficients on white and nonwhite officers, many of the standard critiques regarding bias in the estimation are not directly applicable. An omitted variable that leads to similar biases in both police coefficients would not invalidate comparisons of the relative effects of white and nonwhite officers. Similarly, the likely possibility that increasing crime leads to increases in the size of the police force ${ }^{35}$ does not invalidate the relative comparisons, as long as increasing crime does not alter the racial composition of police forces.

More generally, however, omitted variables and possible endogeneity of the racial composition of the police force could be distorting the results. If

\footnotetext{
${ }^{32}$ The category "other" is primarily Hispanics. Hispanics are expected to report their race as either white or black but many choose "other" instead.

${ }^{33}$ Edward L. Glaeser \& Bruce Sacerdote, Why Is Crime So High in Cities? 107 J. Pol. Econ. S225 (1999); Julie Berry Cullen \& Steven D. Levitt, Crime, Urban Flight, and the Consequences for Cities, 81 Rev. Econ. \& Stat. 159 (1999).

${ }^{34}$ The results of Cullen \& Levitt, supra note 33, suggest that causality runs from crime rates to city population changes and not vice versa. Given that interpretation, including the population variable as regressor in Table 2 may be inappropriate. The results we obtain are not sensitive to excluding the population variable.

${ }^{35}$ Levitt, supra note 17.
} 
it is the case, for instance, that decreasing crime rates (or expectations of declining crime) lead police departments to hire more minorities, then there may be a spurious negative relationship between minority police and the number and composition of arrests. Alternatively, changes in policing strategies (for example, toward community policing) may lead to the hiring of more minority police. It may, however, be the policing strategy rather than the minority officers that is responsible for a change in the pattern of arrests. Since it is difficult to control for changes in policing strategy, the effect will be mistakenly attributed to the minority police.

While the biases in the preceding paragraph suggest that the effectiveness of minority officers may be exaggerated in ordinary least squares regressions, there are other cases in which those results may understate the true impact of minority police. At the beginning of our sample, minorities were greatly underrepresented on police forces. Over the period of our sample, the total number of police increased 28 percent, of which nearly all (25/28) was growth in the number of nonwhite police. To the extent that cities with increasing violent crime tend to hire more police, there may be a spurious link between increasing crime rates and minority police. ${ }^{36}$

Table 3 presents a range of alternative specifications as a means of gauging the sensitivity of our estimates. The columns of Table 3 match those of Table 2. Each set of two rows represents a different specification. Only the differences in the same-race and cross-race arrest coefficients are reported (that is, for odd columns the coefficient on white police minus the coefficient on black police, and for even columns the reverse). A negative value in Table 3 means that arrests are lower with same-race policing than with cross-race policing. The 80 entries in Table 3 (10 sets of rows by eight columns) represent coefficients from 80 different regressions. Coefficients that are statistically significant at the .05 level are indicated by an asterisk.

For purposes of comparison, the top two rows of Table 3 presents the results of Table 2 as a baseline. ${ }^{37}$ The results obtained are robust to a wide range of specifications. Eliminating city fixed effects does remarkably little to change the results. Similarly, little changes when all of the covariates are eliminated except year and city dummies or when region-year interactions (using the nine census regions) are added. The results are more sensitive to the inclusion of city-level trends, and the standard errors increase as well. Restricting the sample to cities with both a substantial black population $(>10$ percent) and a small nonwhite, nonblack population has little systematic effect on the results. This suggests that lumping all nonwhites into one category and including cities with few minorities in the sample is not greatly distorting the results. The coefficients shrink somewhat when robust regression tech-

${ }^{37}$ For instance, in column 1 of Table 3, the value -18.36 corresponds to $.13-18.50$ from the first two sets of rows of Table 2, column 1.
} 
TABLE 3

Sensitivity Analysis of Arrests Rates by Race and Racial Composition of the Police Force: Differential between Same-Race and Cross-Race Arrest Coefficients

\begin{tabular}{|c|c|c|c|c|c|c|c|c|}
\hline \multirow[b]{2}{*}{ SPECIFICATION } & \multicolumn{2}{|c|}{ Total ARrests } & \multicolumn{2}{|c|}{ Property ARRests } & \multicolumn{2}{|c|}{ Violent ARRESTS } & \multicolumn{2}{|c|}{ Drug ARrests } \\
\hline & $\begin{array}{l}\text { White } \\
\text { (1) }\end{array}$ & $\begin{array}{c}\text { Nonwhite } \\
\text { (2) }\end{array}$ & $\begin{array}{l}\text { White } \\
\text { (3) }\end{array}$ & $\begin{array}{c}\text { Nonwhite } \\
\text { (4) }\end{array}$ & $\begin{array}{l}\text { White } \\
\text { (5) }\end{array}$ & $\begin{array}{c}\text { Nonwhite } \\
\text { (6) }\end{array}$ & $\begin{array}{l}\text { White } \\
\text { (7) }\end{array}$ & $\begin{array}{c}\text { Nonwhite } \\
(8)\end{array}$ \\
\hline Baseline & $\begin{array}{r}-18.36^{*} \\
(5.06)\end{array}$ & $\begin{array}{c}-16.70 \\
(10.05)\end{array}$ & $\begin{array}{r}-.69 \\
(.79)\end{array}$ & $\begin{array}{c}-3.52^{*} \\
(1.36)\end{array}$ & $\begin{array}{r}-1.53^{*} \\
(.61)\end{array}$ & $\begin{array}{r}-1.19 \\
(.90)\end{array}$ & $\begin{array}{r}-2.86^{*} \\
(.78)\end{array}$ & $\begin{array}{c}.63 \\
(1.90)\end{array}$ \\
\hline No city fixed effects & $\begin{array}{r}-9.88^{*} \\
(4.64)\end{array}$ & $\begin{array}{r}-22.47 * \\
(9.51)\end{array}$ & $\begin{array}{l}-.65 \\
(.73)\end{array}$ & $\begin{array}{r}-7.42^{*} \\
(1.82)\end{array}$ & $\begin{array}{r}-1.25^{*} \\
(.34)\end{array}$ & $\begin{array}{r}-1.59 \\
(.94)\end{array}$ & $\begin{array}{r}-1.55^{*} \\
(.65)\end{array}$ & $\begin{array}{c}1.21 \\
(1.65)\end{array}$ \\
\hline No economic, socioeconomic, or demographic covariates & $\begin{array}{r}-18.67^{*} \\
(5.82)\end{array}$ & $\begin{array}{c}-16.76 \\
(10.93)\end{array}$ & $\begin{array}{c}-.63 \\
(.76)\end{array}$ & $\begin{array}{c}-3.80^{*} \\
(1.62)\end{array}$ & $\begin{array}{r}-1.91 * \\
(.50)\end{array}$ & $\begin{array}{c}.02 \\
(.97)\end{array}$ & $\begin{array}{r}-4.05^{*} \\
(1.34)\end{array}$ & $\begin{array}{c}3.05 \\
(2.14)\end{array}$ \\
\hline Add region-year interactions & $\begin{array}{r}-24.53^{*} \\
(4.99)\end{array}$ & $\begin{array}{c}-6.54 \\
(9.54)\end{array}$ & $\begin{array}{c}-.88 \\
(.80)\end{array}$ & $\begin{array}{c}-2.38 \\
(1.25)\end{array}$ & $\begin{array}{r}-1.62^{*} \\
(.48)\end{array}$ & $\begin{array}{r}-1.10 \\
(.95)\end{array}$ & $\begin{array}{r}-2.76^{*} \\
(.81)\end{array}$ & $\begin{array}{c}1.26 \\
(1.99)\end{array}$ \\
\hline Add city-specific trends & $\begin{array}{r}-15.88^{*} \\
(7.04)\end{array}$ & $\begin{array}{c}19.21 \\
(13.94)\end{array}$ & $\begin{array}{c}.49 \\
(.98)\end{array}$ & $\begin{array}{c}-1.06 \\
(2.26)\end{array}$ & $\begin{array}{c}.79 \\
(.48)\end{array}$ & $\begin{array}{c}-4.09^{*} \\
(1.29)\end{array}$ & $\begin{array}{l}-.41 \\
(1.30)\end{array}$ & $\begin{array}{l}-.54 \\
(2.20)\end{array}$ \\
\hline Restricted sample: black $>10 \%$, other nonwhite $<10 \%$ & $\begin{array}{r}-11.62^{*} \\
(5.92)\end{array}$ & $\begin{array}{r}-23.26^{*} \\
(11.26)\end{array}$ & $\begin{array}{r}-1.96^{*} \\
(.88)\end{array}$ & $\begin{array}{c}-2.20 \\
(1.62)\end{array}$ & $\begin{array}{r}-1.08^{*} \\
(.45)\end{array}$ & $\begin{array}{c}-1.60 \\
(1.21)\end{array}$ & $\begin{array}{r}-2.42^{*} \\
(.83)\end{array}$ & $\begin{array}{l}-.07 \\
(2.41)\end{array}$ \\
\hline Robust regression & $\begin{array}{c}-6.05 \\
(3.80)\end{array}$ & $\begin{array}{r}-17.64 * \\
(6.12)\end{array}$ & $\begin{array}{c}.07 \\
(.70)\end{array}$ & $\begin{array}{c}-3.90^{*} \\
(1.45)\end{array}$ & $\begin{array}{c}.26 \\
(.19)\end{array}$ & $\begin{array}{c}-.18 \\
(.73)\end{array}$ & $\begin{array}{r}-2.05^{*} \\
(.52)\end{array}$ & $\begin{array}{l}1.77 \\
(.91)\end{array}$ \\
\hline Linearly interpolating EEOC data for missing years $1977-93$ & $\begin{array}{r}-9.20^{*} \\
(3.10)\end{array}$ & $\begin{array}{r}-15.21 * \\
(5.50)\end{array}$ & $\begin{array}{l}.09 \\
(.34)\end{array}$ & $\begin{array}{r}-1.97 * \\
(.78)\end{array}$ & $\begin{array}{r}-.91 * \\
(.27)\end{array}$ & $\begin{array}{c}-1.13^{*} \\
(.45)\end{array}$ & $\begin{array}{r}-1.38^{*} \\
(.53)\end{array}$ & $\begin{array}{c}-.28 \\
(.94)\end{array}$ \\
\hline Two-stage least squares: & & & & & & & & \\
\hline Baseline specification & $\begin{array}{c}-30.19 \\
(18.94)\end{array}$ & $\begin{array}{c}50.40 \\
(47.84)\end{array}$ & $\begin{array}{c}-1.77 \\
(2.58)\end{array}$ & $\begin{array}{c}-5.39 \\
(4.37)\end{array}$ & $\begin{array}{r}-2.25^{*} \\
(1.10)\end{array}$ & $\begin{array}{c}5.42 \\
(3.05)\end{array}$ & $\begin{array}{l}-.60 \\
(3.00)\end{array}$ & $\begin{array}{l}12.56 \\
(6.62)\end{array}$ \\
\hline No city fixed effects & $\begin{array}{c}-3.04 \\
(8.78)\end{array}$ & $\begin{array}{c}-40.43^{*} \\
(16.74)\end{array}$ & $\begin{array}{c}-3.51^{*} \\
(1.16)\end{array}$ & $\begin{array}{c}-9.25^{*} \\
(2.83)\end{array}$ & $\begin{array}{c}.42 \\
(.51)\end{array}$ & $\begin{array}{c}-2.96^{*} \\
(1.33)\end{array}$ & $\begin{array}{c}-.95 \\
(.96)\end{array}$ & $\begin{array}{c}3.00 \\
(1.82)\end{array}$ \\
\hline Add instruments as controls in baseline specification & $\begin{array}{r}-17.85^{*} \\
(5.69)\end{array}$ & $\begin{array}{r}-27.86^{*} \\
(.421)\end{array}$ & $\begin{array}{c}-.85 \\
(.79)\end{array}$ & $\begin{array}{c}-3.24 * \\
(1.44)\end{array}$ & $\begin{array}{r}-1.58^{*} \\
(.66)\end{array}$ & $\begin{array}{r}-2.23^{*} \\
(.97)\end{array}$ & $\begin{array}{r}-3.52^{*} \\
(.88)\end{array}$ & $\begin{array}{r}-1.42 \\
(2.14)\end{array}$ \\
\hline
\end{tabular}

NoтE. - Values in the table reflect the difference between same-race and cross-race coefficients in regressions where arrest rates are the dependent variables. A negative sign implies that arrests are lower with same-race policing. Each entry in the table represents a different regression. The top row corresponds to the specifications reported in Table 2. Other rows differ from the baseline specification as noted in the table. In the two-stage least squares estimates, the racial composition of city firefighters is used as an instrument for the racial composition of the police force. The estimation method is weighted least squares using city populations as weights. EEOC $=$ Equal Employment Opportunity Commission. Standard errors are in parentheses.

* Significant at the .05 level. 
niques are used to reduce the influence of outliers. Nonetheless, three of the eight entries remain negative and statistically significant.

Our data on racial composition of the police force are available only in selected years. In our baseline results, we include only these years in our data set. Data are available on the total number of police in all years, however, so an alternative approach is to include all years in the sample, linearly interpolating the racial composition of the police for the years in which we do not directly observe this information. We present results using this approach in the table.$^{38}$ Seven of the eight point estimates are negative. Although the coefficients are generally smaller than those of our baseline specification (possibly owing to measurement error associated with the linear interpolation), the estimates are more precise as a consequence of the increased number of observations, leading six of the eight estimates to be statistically significant.

The two next-to-last sets of rows of Table 3 present two-stage least squares (2SLS) estimates using the racial composition of a city's firefighters as an instrument for the racial composition of the police force. ${ }^{39}$ Even after controlling for the racial composition of city residents, the number of nonwhite municipal firefighters is a good predictor of the number of nonwhite police but is only weakly correlated with the number of white police. Similarly, the number of white employees in those other functions is correlated with the number of white police, but not with the number of nonwhite police. ${ }^{40} \mathrm{Be}$ cause of large standard errors, it is difficult to draw strong conclusions from the 2SLS estimates when city fixed effects are included (the penultimate set of rows). When city fixed effects are dropped from the 2SLS regressions, however, statistically significant negative coefficients are obtained in four of the eight columns.

An important concern in interpreting the 2SLS coefficients is whether the exclusion of firefighters from the crime equation is valid. While one would certainly not expect a direct impact of the composition of the fire department on crime rates, it is possible that a large number of black firefighters is the

\footnotetext{
${ }^{38}$ To make the results consistent across years, we replace our measure of the number of police officers (taken from EEOC reports and therefore available only in select years) with the number of police as reported in the Uniform Crime Reports. The EEOC and FBI measures of total police are very highly correlated in the years in which EEOC data are available, so this change has little impact on our findings.

${ }^{39}$ More precisely, our measure of firefighters is those employees of the fire department who are involved in protective service. Firefighters are classified as either white or nonwhite, as was the case with police.

${ }^{40}$ The first-stage regression coefficients are as follows. Each additional white firefighter is associated with a .45 (standard error $(\mathrm{SE})=.07$ ) increase in the number of white police officers, whereas each nonwhite firefighter is associated with a $-.14(\mathrm{SE}=.16)$ change in the number of white police. When nonwhite police is the dependent variable, the coefficient on nonwhite firefighters is $.62(\mathrm{SE}=.16)$ and the coefficient on white firefighters is .02 ( $\mathrm{SE}=$ .06). It is worth noting that similar first-stage regressions using jobs that less closely parallel policing, such as garbage collection, streets and highways maintenance, and administration, were not systematically correlated with the composition of the police force.
} 
consequence of other factors about a city that will influence crime, such as good race relations or a thriving minority community. ${ }^{41}$ Under the assumption that the composition of the fire department captures important omitted factors of a city's situation, these variables should be included as controls, not used as instruments. The final set of rows of the table adds the firefighter variables as regressors. The coefficients are similar to those from the baseline specification, which suggests that firefighter composition is not capturing important omitted factors.

Summarizing Table 3, over four-fifths of the coefficients presented are negative. All 37 of the coefficients that are statistically significant at the .05 level carry a negative sign. The only column for which a statistically significant negative sign is never obtained is for nonwhite drug arrests.

\section{Estimating the Relationship between Same-Race and Cross-Race Policing and Crime Rates}

As noted in the theoretical section of this paper, there are a number of possible explanations for the lower level of arrests that is observed with same-race policing: (1) victim reporting of crime may be lower when the police officers are of the same race as the victim; (2) same-race police officers may be more effective in deterring or solving crime, leading to fewer crimes being committed and consequently fewer arrests; (3) same-race police may make fewer false/harassment-based arrests; (4) same-race police officers may have a higher standard of proof for making an arrest when there is room for discretion; or (5) same-race police officers may be less effective in solving crimes, perhaps owing to more police corruption.

Of these five explanations, only the first seems directly at odds with common sense-precisely the opposite story (that is, increased reporting of crime by victims to officers of the same race) would be expected. Distinguishing between the other four explanations is critical to understanding the welfare implications of our findings on arrests. If same-race police are more effective in deterring crime, then fewer same-race arrests will be accompanied by lower crime rates than would be the case with cross-race policing. If samerace police make fewer false arrests, but are otherwise no different than cross-race police, then arrest rates will be lower, but crime will not be directly affected. The other two scenarios (higher standard of proof and corruption) predict that lower arrest rates will be accompanied by increasing crime since expected punishments will be lower. In this section, we propose some approaches to disentangling the competing explanations. First, we examine our estimated effects of changing police demographics on arrest rates to see if the different patterns across the different crime categories can give us any

\footnotetext{
${ }^{41}$ At a minimum, these instruments should be free of any contamination in the police variables that arises from endogenous manipulation of the police force composition in response to either increasing crime rates or changes in policing strategies.
} 
insight into the underlying causal relationships. Second, we consider how changes in crime in our panel data can help sort out which effects are operating, although limitations in the current crime data limit the progress we are able to make empirically.

First, the top line of estimates in Table 3 reveals that same-race policing leads to substantially fewer "total" arrests than does cross-race policing and that this pattern is not nearly as strong for the other three crime categories (indeed, the pattern does not apply at all for drug arrests of nonwhites). The more powerful effects in the total arrest category likely emanate from the different impact of the race of police on public order offenses, prostitution, drunk driving, and a wide range of other generally minor crimes. In other words, for more discretionary arrests that are less likely to be generated by victim complaints, we see stronger drops in arrests with more same-race policing, which is suggestive of fewer harassing arrests or possibly less racial profiling with same-race policing. While the effects are less strong in the other three categories, we do see that same-race policing leads to greater declines in property arrests of nonwhites and violent and drug arrests of whites. $^{42}$

Second, if crime data by race were available, it would be straightforward to estimate the relationship between the racial composition of the police force and crime by race, much as we did for arrests in the preceding section. Unfortunately, data on crime commission by race are not available annually at the city level, nor can they be reliably imputed from victimization data. ${ }^{43}$

At least in theory, however, there is an indirect means of estimating a racespecific crime impact using city-level crime data (not broken down by race). This indirect approach requires imposing assumptions about the way white and nonwhite officers are assigned to patrol beats (which in turn dictates the distribution of arrest opportunities). Our baseline assumption is that white and nonwhite officers are randomly assigned to neighborhoods. ${ }^{44}$ If this is the case, then white and nonwhite officers would each expect to face the same distribution of arrest opportunities. Denote the efficiency with which

${ }^{42}$ Given the common racial segregation of gangs that sell drugs, one could imagine that efforts to arrest drug dealers of a certain race, perhaps through undercover work, might be facilitated by having more officers of that race. Conversely, there have been instances where drug gangs have placed high-ranking gang leaders into city police departments as a way to minimize arrests. Matt O'Connor, Court Told Austin Officer Only Posed as Crooked Cop, Chi. Trib., May 15, 1998, at A9, discusses how the Vice Lords street gang was able to infiltrate the ranks of the Chicago Police Department.

${ }^{43}$ The number of interviewees in the National Crime Victimization Survey, even for large cities, is very small. Also, while the overall sample is nationally representative, at the local level this is not the case owing to the sampling methodology based on clusters.

${ }^{44}$ Anecdotal evidence suggests that nonwhite officers may be disproportionately assigned to nonwhite neighborhoods. If police are not randomly assigned by race, the coefficients still provide information on the impact of the race of officers and citizens on crime, but a scaling factor accounting for the distribution of arrest opportunities must be incorporated in order to interpret the results on a per-officer basis. 
crimes committed by criminals of race $i$ are reduced with each additional officer of race $j$ as $\beta_{i j}$. Allowing crime rates to systematically differ across race by a proportion $\gamma$, and assuming $\gamma$ is constant over time for a given city, we can model the total impact of police on crime as

$$
\begin{aligned}
\text { Crime }= & \beta_{\mathrm{ww}}\left(\text { White } \times P_{\mathrm{w}}\right)+\beta_{\mathrm{nw}}\left(\gamma(1-\text { White }) \times P_{\mathrm{w}}\right) \\
& +\beta_{\mathrm{wn}}\left(\text { White } \times P_{\mathrm{n}}\right)+\beta_{\mathrm{nn}}\left(\gamma(1-\text { White }) P_{\mathrm{n}}\right),
\end{aligned}
$$

where Crime is total crime per capita in the city and year, White is the fraction of the population that is white, and the subscripts " $w$ " and " $n$ " correspond to white and nonwhite, respectively. All other variables are as defined above. Adding in the appropriate control variables and an error term, one can estimate equation (10) with a city-level panel using only aggregate crime data. The goal of this exercise would be to provide separate estimates of the relative impact of white and minority police on white crime $\left(\beta_{\mathrm{ww}}\right.$ and $\left.\beta_{\mathrm{wn}}\right)$ and on minority crime $\left(\beta_{\mathrm{nw}}\right.$ and $\left.\beta_{\mathrm{nn}}\right){ }^{45}$

An earlier version of this paper ${ }^{46}$ presented empirical estimates of equation (10). The results, however, are sensitive to the choice of sample and the particular crime category examined ${ }^{47}$ Furthermore, as a check on the reliability of this approach, we have estimated equation (10) using arrest data as the dependent variable. If this indirect estimation approach is valid, one would expect the results from this indirect method to generate coefficients similar to those presented in Section III. While there is some correspondence between these two sets of estimates, it is far weaker than might be hoped.

\section{Conclusions}

This paper analyzes the role of race in policing, first developing a theoretical model and then estimating that model using panel data for 122 large U.S. cities. The finding of the paper is that the addition of officers of a given race is associated with an increase in the number of arrests of suspects of a different race but has little impact on same-race arrests. Extrapolating from the coefficients obtained, we estimate that moving from random assignment of officers by race to a scenario in which same-race policing is maximized would lead arrests to decrease by over 15 percent.

\footnotetext{
${ }^{45}$ Note that $\beta_{\mathrm{nw}}$ and $\beta_{\mathrm{nn}}$ cannot be separately identified from $\gamma$. Nonetheless, the presence of $\gamma$ does not create a problem because it is only the relative magnitude of $\beta_{\mathrm{nw}}$ and $\beta_{\mathrm{nn}}$ that is required to assess the relative effectiveness of white and nonwhite officers.

${ }^{46}$ John Donohue \& Steven D. Levitt, The Impact of Race on Policing, Arrest Patterns, and Crime (unpublished manuscript, Univ. Chicago, Dept. Econ. 1999).

${ }^{47}$ For instance, many of the signs on the key coefficients flip when we linearly interpolate the racial composition of the police data for the years in which we have information only on the number of police. The sensitivity of the results to this procedure, which had little impact on the estimates of arrest rates, now makes us skeptical of the crime-related estimates presented in $i d$.
} 
A number of points should be noted about our major finding. First, it tends to refute that portion of the police literature discussed above that argued that officer race does not matter. Specifically, an array of studies concluded that the process of occupational socialization rather than race was the important determinant of police officer attitude and conduct-a view that is difficult to reconcile with our finding of a differential pattern of arrests across races. Second, while the racial pattern in arrests is noteworthy, we remain uncertain as to the normative significance of the finding. In other words, we do not yet know whether the significant increases in arrests for whites when more nonwhite police are hired is desirable because they restore greater equality in the likelihood of arrest conditional on the existence of unlawful conduct or because the higher rates of arrest lead to greater decreases in the number of crimes committed by whites (and vice versa). Nor do we know if these increases in cross-race arrests suggest that greater harassment is being perpetrated or that cross-race policing is less effective because crime and, correspondingly, arrests are higher when such policing is more prevalent.

At present, the absence of accurate data on the race of offenders hampers the effort to resolve these questions. Ideally, one would aspire to collect data from a number of cities combining information on the levels of crime and the assignment of officers by race within urban police departments and the race of both the arresting officer and the individuals arrested. By analyzing this richer set of data, one would be able to understand the reasons for the increase in cross-race arrests and the impact of police demographics on crime overall and by race. In particular, the National Crime Victimization Survey may in the future provide an opportunity to test these hypotheses more explicitly, if the data were to be made available to researchers at a more disaggregated level.

\section{BIBLIOGRAPHY}

Akerlof, George, and Yellen, L. Janet. "Gang Behavior, Law Enforcement, and Community Values." In Values and Public Policy, edited by Henry J. Aaron, Thomas E. Mann, and Timothy Taylor. Washington, D.C.: Brookings Institution, 1994.

Alex, Nicholas. Black in Blue: A Study of the Negro Policeman. New York: Appleton Press, 1969.

Ashenfelter, Orley; Heckman, James; and Joseph, James. "Measuring the Effect of an Antidiscrimination Program." In Evaluating the Labor Market Effects of Social Programs, edited by Orley Ashenfelter and James Blum. Princeton, N.J.: Princeton University Press, 1975.

Bowles, Roger, and Garoupa, Nuno. "Casual Police Corruption and the Economics of Crime." International Review of Law and Economics 17 (1997): 75-87.

Brown, Charles. "Black-White Earnings Ratios since the Civil Rights Act 
of 1964: The Importance of Labor Market Dropouts." Quarterly Journal of Economics 99 (1984): 31-44.

Cameron, Samuel. "The Economics of Crime Deterrence: A Survey of Theory and Evidence." Kyklos 41 (1988): 301-23.

Crosby, Faye; Bromley, Stephen; and Saxe, Leonard. "Recent Unobtrusive Studies of Black and White Discrimination and Prejudice." Psychological Bulletin 87 (1980): 546-63.

Cullen, Julie Berry, and Levitt, Steven D. "Crime, Urban Flight, and the Consequences for Cities." Review of Economics and Statistics 81 (1999): 159-69.

Decker, Scott H., and Smith, Russell L. "Police Minority Recruitment: A Note on Its Effectiveness in Improving Black Evaluations of the Police." Journal of Criminal Justice 8 (1980): 387-93.

Donohue, John, and Levitt, Steven D. "The Impact of Race on Policing, Arrest Patterns, and Crime." Unpublished manuscript. Chicago: University of Chicago, Department of Economics, 1999.

Equal Opportunity Employment Commission. Job Patterns for Minorities and Women in State and Local Government 1993. Washington, D.C.: U.S. Government Printing Office, 1995.

Federal Bureau of Investigation. Uniform Crime Reports. Washington, D.C.: U.S. Department of Justice, Federal Bureau of Investigation, various editions.

Glaeser, Edward L., and Sacerdote, Bruce. "Why Is Crime So High in Cities?" Journal of Political Economy 107 (1999): S225-S258.

Groves, Eugene W., and Rossi, Peter H. "Police Perceptions of a Hostile Ghetto." American Behavioral Scientist 13 (1970): 727-43.

Heckman, James J., and Wolpin, Kenneth I. "Does the Contract Compliance Program Work? An Analysis of Chicago Data." Industrial and Labor Relations Review 29 (1976): 544-64.

Hochstedler, E., and Conley, J. "Explaining Underrepresentation of Black Officers in City Police Agencies." Journal of Police Science and Administration 6 (1986): 168-83.

Knapp Commission. The Knapp Commission Report on Police Corruption. New York: George Braziller, 1972.

Krieger, Linda Hamilton. "The Content of Our Categories: A Cognitive Bias Approach to Discrimination and Equal Employment Opportunities." Stanford Law Review 47 (1995): 1161-248.

Lasley, James R. "Ethnicity, Gender, and Police-Community Attitudes." Social Science Quarterly 75 (1994): 85-97

Leonard, Jonathan S. "The Impact of Affirmative Action on Employment." Journal of Labor Economics 2 (1984): 439-63.

Leonard, Jonathan S. "The Impact of Affirmative Action Regulation and Equal Employment Law on Black Unemployment." Journal of Economic Perspectives 4 (1990): 47-63. 
Levitt, Steven D. "Using Electoral Cycles in Police Hiring to Estimate the Effect of Police on Crime." American Economic Review 87 (1997): 270-90.

Lott, John R., Jr. "Does a Helping Hand Put Others at Risk? Affirmative Action, Police Departments, and Crime." Economic Inquiry 38 (2000): 239-77.

Marvell, Thomas B., and Moody, Carlisle E. "Specification Problems, Police Levels, and Crime Rates." Criminology 34 (1996): 609-46.

Mast, R. "Police-Ghetto Relations: Some Findings and a Proposal for Structural Change." RACE 11 (1970): 447-62.

Mauer, Marc, and Huling, Tracey. Young Black Americans and the Criminal Justice System: Five Years Later. Washington, D.C.: Sentencing Project, 1995.

Mauro, Paolo. "Corruption and Growth." Quarterly Journal of Economics 110 (1995): 681-712.

McCormick, Robert E., and Tollison, Robert D. "Crime on the Court." Journal of Political Economy 92 (1984): 223-35.

Monkkonen, Eric H. "History of Urban Police.” In Modern Policing, edited by Michael H. Tonry and Norval Morris. Chicago: University of Chicago Press, 1992.

Moore, Mark Harrison. "Problem-Solving and Community Policing." In Modern Policing, edited by Michael Tonry and Norval Morris. Chicago: University of Chicago Press, 1992.

Morton, James. Bent Coppers: A Survey of Police Corruption. London: Little, Brown, 1993.

National Association for the Advancement of Colored People. Beyond the Rodney King Story: An Investigation of Police Conduct in Minority Communities. Boston: Northeastern University Press, 1995.

O'Connor, Matt. "Court Told Austin Officer Only Posed as Crooked Cop." Chicago Tribune, May 15, 1998, p. A9.

Olson, Mancur, Jr. "Why Poor Economic Policies Must Promote Corruption: Lessons from the East for All Countries." Rivista di Politica Economica 111 (1996): 9-51.

President's Commission on Law Enforcement and Administration of Justice. Task Force Report: The Police. Washington, D.C.: U.S. Government Printing Office, 1968.

Rodgers, William M. III, and Spriggs, William E. "The Effect of Federal Contractor Status on Racial Differences in Establishment-Level Employment Shares: 1979-1992.” American Economic Review 86 (1996): 290-93.

Sherman, Lawrence W. "Causes of Police Behavior: The Current State of Quantitative Research." Journal of Research in Crime and Delinquency 17 (1980): 69-100. 
Shleifer, Andrei, and Vishny, Robert W. "Corruption." Quarterly Journal of Economics 108 (1993): 599-617.

Skogan, Wesley. "Fear of Crime and Neighborhood Change." In Crime and Justice: A Review of Research, edited by Michael H. Tonry and Norval Morris. Chicago: University of Chicago Press, 1986.

Skolnick, Jerome H., and Bayley, David H. The New Blue Line: Police Innovation in Six American Cities. New York: Free Press, 1986.

Stokes, Larry D., and Scott, James F. "Affirmative Action Policy Standard and Employment of African Americans in Police Departments." Western Journal of Black Studies 17 (1993): 135-42.

U.S. Kerner Commission. Report of the National Advisory Commission on Civil Disorders. New York: Bantam Books, 1968.

U.S. Kerner Commission. United States Kerner Commission Report. New York: Dutton, 1968.

Walker, Samuel. A Critical History of Police Reform: The Emergence of Professionalism. Lexington, Mass.: Lexington Books, 1977.

Walker, Samuel. "Employment of Black and Hispanic Police Officers: Trends in the 50 Largest Cities." Review of Applied Urban Research 11 (1983): $1-6$.

Wilson, James Q. Varieties of Police Behavior: The Management of Law and Order in Eight Communities. Cambridge, Mass.: Harvard University Press, 1968.

Wilson, James Q. Thinking about Crime. New York: Basic Books, 1983. 